\title{
PENGEMBANGAN SKALA SOCIAL DESIRABILITY
}

\author{
Ricky Oktapialdi, Medianta Tarigan, M. Ariez Musthofa \\ Departemen Psikologi Universitas Pendidikan Indonesia \\ Email: Oktapialdi.Ricky@gmail.com,medianta.tarigan@gmail.com,ariezmusthofa@yahoo.com
}

\begin{abstract}
This research aims to develop a social desirability scale in Indonesian. The method used is mixed method. Participant in the exploration stage amounted to 400 subjects. Whereas, in the second stage, which purposed to identify a psychometric properties (reliability and validity), participant amounted to 501 subjects. Data analysis in the first stage was open coding. For the second stage data analysis consisted of reliability estimation using Cronbach's Alpha and test of construct validity using factorial validity with Confirmatory Factor Analysis (CFA) and convergent validity. The Result shows that the scale has a high reliability coefficient $(\alpha=0.76)$. Whereas, the test of model fit with CFA shows that the scale fits with the data with index of fit value of Comparative Fit Index $(C F I)=0.92$, Goodness of Fit Index $(G F I)=0.93$, Root Mean Square of Approximation $(R M S E A)=0.059$, and Standardized Root Mean Residual $($ SRMR $)=$ 0.052. A convergent validity also tested by correlating social desirability Indonesian scale with social desirability scale by Reynolds (1982).
\end{abstract}

Key words: Social Desirability, Reliability, Construct Validity, Convergent Validity.

\begin{abstract}
Abstrak
Tujuan penelitian ini adalah untuk melakukan pengembangan skala social desirability di Indonesia. Metode penelitian yang digunakan dalam penelitian ini merupakan metode campuran (Mixed method). Partisipan pada tahap pertama yang bertujuan untuk mengeksplorasi tema aitem berjumlah 400 orang. Sementara, partisipan pada tahap kedua yang bertujuan untuk melakukan identifikasi karaktersitik psikometri (reliabilitas dan validitas) berjumlah 501 orang. Teknik analisis data yang digunakan terdiri dari open coding untuk tahap pertama. Sedangkan, untuk tahap kedua terdiri dari estimasi reliabilitas dengan menggunakan Alpha Cronbach, serta uji validitas konstruk menggunakan validitas faktorial dengan confirmatory factor analysis (CFA) dan validitas konvergen. Hasil yang diperoleh menunjukan bahwa skala yang dikembangkan memiliki koefisien reliabilitas yang tinggi $(\alpha=0.76)$. Sementara, uji kecocokan model dengan CFA menunjukan hasil yang fit dengan nilai indeks kecocokan Comparative Fit Index $(\mathrm{CFI})=0.92$, Goodness of Fit Index $(\mathrm{GFI})=0.93$, Root Mean Square of Approximation $($ RMSEA $)=0.059$, dan Standardized Root Mean Residual $($ SRMR) $=0.052$. Validitas konvergen diuji dalam penelitian ini dengan mengkorelasikan skala social desirability Indonesia dengan skala social desirability dari Reynolds (1982).
\end{abstract}

Kata Kunci: Social Desirability, Relibilitas, Validitas Kontruk, Validitas Konvergen

\section{PENDAHULUAN}

Dalam pengetesan psikologi, sudah sejak lama disadari bahwa skor tes kepribadian dipengaruhi oleh faktor non-tes (Marlowe \& Crowne, 1960). Salah satu faktor non-tes yang harus dihadapi oleh peneliti adalah permasalahan mengenai kebenaran informasi yang 
diberikan oleh responden. Tidak dapat dipungkiri bahwa kecenderungan seseorang untuk menjawab sebuah kuesioner psikologi dengan respon yang lebih menguntungkan bagi dirinya maupun respon yang lebih diterima masyarakat dapat membuat peneliti mengambil kesimpulan yang salah (Barick \& Mount, 1996; Jaya, dkk, 2011). Sehingga, permasalahan ini pada akhirnya dapat menyebabkan variabel yang diteliti bisa saja memiliki hubungan yang semu atau bahkan meniadakan hubungan diantara variabel tersebut (Mortel, 2008). Widhiarso (2011) juga menambahkan bahwa kuesioner yang disajikan secara mandiri (self report) dapat memberikan peluang pada responden yang memiliki motif-motif tertentu untuk memberikan informasi yang palsu. Istilah yang biasa digunakan untuk menjelaskan fenomena tersebut adalah social desirability. Namun demikian, banyak peneliti yang seakan masih menutup mata terhadap fenomena ini (Burns, 2003). Ditambah, penelitian-penelitian mengenai social desirability ini masih sangat kurang, khususnya di Indonesia. Padahal, respon social desirability ini merupakan sumber bias pada hasil penelitian yang perlu diatasi (Widhiarso, 2011)

Social desirability didefinisikan sebagai suatu kecenderungan untuk memberikan respon yang positif sebagai gambaran diri (Paulhus, 2002). Sementara, Sjostrom \& Holst (dalam Widhiarso, 2012) menjelaskan bahwa respon social desirability merupakan respon individu terhadap pertanyaan yang diberikan, dimana individu tersebut berusaha untuk meningkatkan kesamaan dengan karakteristik masyarakat dan menurunkan apa yang tidak diharapkan masyarakat. Sehingga, jawaban yang diberikan oleh individu tersebut menjadi tidak sesuai dengan keadaan sebenarnya.

Mortel (2008) menunjukkan bahwa social desirability memiliki pengaruh yang signifikan pada penelitian dengan konteks perilaku kekerasan dalam rumah tangga, sejarah kriminalitas dan gangguan jiwa, tingkat kegiatan fisik, tingkat stres psikologis, kekerasan pada pasangan tingkat pemakaian narkoba dan alkohol, serta pola makan. Sehingga, tentu saja pengadministrasian skala social desirability sebagai variabel kontrol bersamaan dengan skala lain yang rentan terkena bias ini dapat menjadi salah satu upaya untuk meminimalisir hasil penelitian yang semu (Dijkstra, 2001).

Salah satu skala yang kerap kali digunakan sebagai alat untuk mengukur respon social desirability adalah skala yang dikembangkan oleh Marlowe \& Crowne (1960) yang dinamakan The Marlowe Crowne Social Desirability. Skala tersebut merupakan skala social desirability yang terkenal yang biasa digunakan di Barat (Epinosa \& Vijver, 2016). Marlowe Crowne Social Desirability Scale (1960) merupakan sebuah skala yang digunakan untuk mengukur respon social desirability yang terdiri dari 33 aitem pernyataan dengan nilai reliabilitas sebesar 0.88. Skala ini dibuat berdasarkan aitem skala kepribadian dari berbagai inventori yang dipublikasikan sekitar tahun 50an (Espinosa \& Vijver, 2014).

Namun demikian, skala tersebut belum banyak digunakan di Indonesia. Ditambah, ketika skala tersebut digunakan di Indonesia mungkin saja akan menjadi hal yang kurang tepat, sebagaimana Espinosa \& Vijver (2014) menyatakan bahwa penggunaan skala social desirability dapat memunculkan beberapa permasalahan ketika digunakan untuk populasi 
non-Barat. Beberapa permasalahan tersebut diantaranya, adanya beberapa aitem dari skala tersebut yang tidak memiliki kekuatan diskriminan atau aitem yang menampakkan konten yang tidak relevan ketika diadaptasi kedalam budaya lain (Collazo, 2005; Ribas dkk, 2004).

Dalam pengembangan alat ukur, tentu harus memperhatikan kebudayaan dimana suatu alat ukur dibuat. Karena, perbedaan budaya dapat memberikan sumbangan terhadap pembentukan konsep psikologi dari seorang individu yang berbeda pula. Sebagaimana Kim dan Park (2006) menyatakan bahwa budaya memiliki peranan yang sangat sentral dalam mempersepsi fenomena sosial. Negara Indonesia yang merupakan negara dengan suku yang beragam dan juga negara kolektif memiliki kepribadian yang berbeda dengan budaya Barat yang lebih individualis. Maka dari itu, diperlukan suatu pendekatan yang dapat menjelaskan perbedaan-perbedaan tersebut.

Indigenous psychology menghadirkan sebuah pendekatan yang dapat digunakan dalam konteks pengukuran atribut psikologi. Kim \& Berry (1993) menerangkan bahwa indigenous psychology sebagai kajian ilmiah mengenai perilaku dan mental manusia yang bersifat pribumi, tidak dibawa dari daerah lain, dan didesain untuk masyarakatnya sendiri. Pendekatan indigenous ini sendiri pada dasarnya berpijak pada cara berpikir constructive realism. Dimana, penerapan constructive realism pada pendekatan indigenous ini menunjukkan bahwa generalisasi dari fakta empiris merupakan tantangan bagi setiap keilmuan (Kim dkk., 2006).

Di luar negeri, penelitian dengan pendekatan indigenous yang berkaitan dengan pengembangan alat ukur social desirability pernah dilakukan oleh Espinosa dan Vijver (2014), tepatnya di Meksiko. Sementara, belum banyak penelitian yang menggunakan pendekatan indigenous psychology di Indonesia, terutama dalam konteks pengembangan alat ukur. Namun demikian, salah satu contoh dari penggunaan pendekatan indigenous psychology dalam penelitian alat ukur dapat dilihat dari penelitian yang pernah dilakukan oleh Widhiarso \& Anggono (2010) yang mengembangkan alat ukur kebahagiaan. Mereka menggunakan kuesioner open-ended untuk menemukan kekhasan kebahagiaan masyarakat Indonesia. Hasil daripada kuesioner tersebut dijadikan tema dasar untuk kemudian diturunkan menjadi aitem-aitem pertanyaan. Berdasarkan pemaparan di atas, peneliti tertarik untuk melakukan pengembangan skala social desirability. Dalam hal ini, dengan pendekatan indigenous, peneliti mencoba untuk mengeksplorasi tema-tema perilaku yang berkaitan dengan social desirability yang muncul pada konteks masyarakat Indonesia, untuk kemudian dibuat menjadi aitem skala. Penelitian kali ini juga menggunakan skala social desirability dari Reynolds (1982) sebagai kriteria untuk validasi konvergen. Skala ini dipilih karena memiliki nilai reliabilitas dan juga validitas faktorial dengan ketetapan model yang lebih baik daripada skala versi lengkapnya (Reynolds, 1982). Pengembangan skala social desirability ini didasari oleh fakta bahwa belum adanya alat ukur social desirability yang dikembangkan dengan menggunakan konteks khas Indonesia. Serta, berdasarkan pendekatan indigenous, alat ukur Barat yang biasanya mengukur respon social desirability juga belum 
tentu cocok digunakan dalam kebudayaan Indonesia yang notabene merupakan negara kolektif.

\section{Social Desirability}

Social desirablility merupakan suatu set kecenderungan seorang subjek dalam merespon pernyataan dalam tes kepribadian dengan tujuan untuk memberikan kesan lebih positif atau menunjukan sikap yang secara sosial diterima masyarakat (Mick, 1996; Paulhus, 2002). Pengukuran respon social desirable telah banyak dilakukan untuk mereduksi atau membenarkan kecenderungan self-image yang terdistorsi dan self-presentation yang tidak realistis (Paulhus, 2002).

Edwards (dalam Crowne \& Marlowe, 1960) menyatakan bahwa pengukuran social desirability dapat digunakan sebagai salah satu upaya untuk mengatasi permasalahan dalam distorsi respon. Permasalahan-permasalahan dalam respon social desirability ini dapat mengecoh peneliti untuk kemudian menarik kesimpulan yang salah (Jaya, Hartana, \& Mangundjaya, 2011) karena respon social desirability ini dapat menjadi bias dan membentuk hubungan semu (Van de Mortel, 2008; Widhiarso, 2011) dengan cara melemahkan, memoderasi, maupun memalsukan korelasi diantara variabel penelitian yang dikaji (Ganster, Hennessey, \& Luthan, 1983).

\section{Penelitian Skala Social Desirability}

Pada tahun 1960, Marlowe dan Crowne mengembangkan skala social desirability. Skala ini terdiri dari 33 item pernyataan dengan pilihan jawaban "Benar" atau "Salah." Pengembangan item skala Marlow-Crowne social desirability ini dibuat dengan mengumpulkan inventori kepribadian (Marlowe \& Crowne, 1960). Item-item dari inventori kepribadian tersebut kemudian dipilih berdasarkan aitem yang menjelaskan perilaku yang secara budaya dapat diterima oleh masyarakat serta sulit atau jarang ditemukan dalam kejadian sehari-hari (Reynolds, 1982). Skala yang dikembangkan oleh Marlowe \& Crowne ini memiliki nilai reliabilitas sebesar 0.88 (Marlowe \& Crowne, 1960).

\section{Pengembangan Skala Social Desirability Versi Pendek}

Karena dirasa bahwa item dari Marlowe \& Crowne social desirability scale terlalu banyak jika digunakan bersamaan dengan skala kepribadian lain (Fisher, 2000), maka banyak peneliti yang membuat versi pendek (short form) dari skala ini, salah satu diantaranya adalah Reynolds (1982). Pada tahun 1982, Reynolds beranggapan bahwa skala social desirability dari Marlowe dan Crowne (1960) memiliki item yang terlalu banyak dan terkadang lebih banyak dari skala kepribadian yang digunakan dalam penelitian, padahal skala ini berfungsi sebagai variabel kontrol. Sehingga, dia kemudian mengembangkan versi pendek dari skala social desirability Marlowe Crowne. 
Reynolds (1982) dalam penelitiannya menggunakan sampel sebanyak 608 orang mahasiswa. Ia membuat 3 versi pendek skala dengan jumlah item masing-masing untuk setiap versi adalah 11, 12, dan 13 item. Hasilnya, versi skala yang terdiri dari 13 item dapat digunakan untuk mensubstitusi skala dari Marlowe dan Crowne yang berjumlah 33 item, dengan nilai reliabilitas sebesar 0.76. Sementara, untuk versi skala yang memiliki item sebanyak 11 dan 12 masing masing memiliki reliabilitas sebesar 0.74 dan 0.75 yang tidak jauh berbeda dengan versi pendek lainnya.

Pada penelitian ini, akan dipakai skala social desirability versi pendek dari Reynolds yang memiliki reliabilitas tertinggi yaitu skala yang terdiri dari 13 item, untuk digunakan sebagai kriteria validasi konvergen. Hal ini didasarkan bahwa skala social desirability versi pendek dari Reynolds memiliki reliabilitas yang cenderung lebih tinggi daripada versi pendek yang dikembangkan oleh peneliti lain serta memiliki validitas faktorial dengan kecocokan model yang lebih baik daripada versi lengkap skalanya (Barger, 2002; Reynolds, 1982).

\section{Struktur Faktor Skala Social Desirability}

Pada awal pembuatannya, Marlowe \& Crowne (1960) tidak meneliti struktur faktor dari skala social desirability yang dikembangkannya. Beberapa penelitian kemudian menunjukan bahwa karakteristik reliabilitas dan struktur faktor dari skala social desirability Marlowe \& Crowne (1960) tidak stabil baik pada versi total maupun pada versi pendek yang banyak dikembangkan (Barger 2002; Loo \& Thorpe 2000).

Ramanaiah dkk. (1977) melakukan penelitian untuk menguji hipotesis 2 faktor skala social desirability Marlowe \& Crowne (1960). Hasil penelitian ini merupakan bukti empiris yang mendukung Hipotesis Milham (1974) yang menyatakan bahwa attribution dan denial merupakan 2 komponen terpisah dari skala Marlowe dan Crowne (1980). Hasilnya mereka menemukan bahwa attribution dan denial merupakan dua komponen mayor pada skala social desirability Marlowe \& Crowne (1960) dengan melakukan interkorelasi faktor antar aitem dengan menggunakan korelasi multi-group common factor analysis, sehingga hasil ini mendukung hipotesis 2 faktor pada skala tersebut (Ramanaiah, dkk, 1977). Attribution sendiri merujuk pada persetujuan perilaku baik atau diharapkan, namun jarang dilakukan. Sementara, Denial merujuk pada penolakan terhadap perilaku kurang baik atau negatif namun seringkali dilakukan (Espinosa \& Vijver, 2014).

Karena pada penelitian ini eksplorasi hanya dilakukan pada tingkatan tema item dan tidak bertujuan untuk menemukan faktor baru, maka model 2 faktor dari Ramanaiah dkk (1977) ini nantinya akan digunakan sebagai model awal skala social desirability Indonesia. 


\section{METODE}

Penelitian ini memiliki tujuan untuk melakukan pengembangan skala social desirability Indonesia. Metode yang digunakan dalam penelitian ini adalah metode campuran (mixed method). Menurut Creswell (2011) mixed method merupakan suatu prosedur untuk mengumpulkan, menganalisis, dan menggabungkan antara metode kuantitatif dan kualitatif dalam sebuah studi atau sebuah seri studi untuk dapat memahami sebuah permasalahan penelitian. Model mixed methods yang digunakan adalah mendahulukan penelitian kualitatif dalam pelaksanaannya daripada kuantitatif. Model ini sangat sesuai dengan tujuan pengembangan alat ukur (Creswell, 2011).

Uji reliabilitas dalam penelitian ini menggunakan Alpha Cronbach. Sementara, uji validitas dalam penelitian ini dilakukan dengan menggunakan teknik validitas konstruk. Secara lebih spesifik, validitas konstruk yang digunakan untuk menguji skala social desirability Indonesia adalah metode confirmatory factor analysis (CFA). CFA digunakan karena pengembangan skala ini mencoba mengkonfirmasi dan menggunakan model 2 faktor social desirability yang dibuat oleh Ramanaiah dkk. (1977). Metode validasi lain yang digunakan dalam penelitian ini juga adalah validasi konvergen, yang merupakan teknik validasi dengan mengkorelasikan dua skala yang mengukur konstruk yang sama.

Pengambilan data dalam penelitian ini terbagi menjadi dua tahap. Pada tahap pertama, peneliti mengambil sampel sebanyak 400 orang. Tujuannya untuk mengeksplorasi tematema yang akan digunakan dalam pengembangan instrumen. Sementara, pengambilan data pada tahap kedua jumlah responden sebanyak 501 orang. Kuantitas sampel ini sudah termasuk dalam kategori very good untuk dilakukan analisis faktor menurut kriteria rule of thumb dari Van Voorhis \& Moorgan (2007).

Teknik pengambilan sampel dalam penelitian ini menggunakan teknik nonprobability sampling dengan convenience sampling. Pengumpulan data tahap 1 dilakukan dengan menggunakan kuesioner open ended yang dibuat oleh peneliti untuk mencari tema khas social desirability dalam konteks masyarakat Indonesia. Sementara, pada tahap kedua untuk melakukan validasi instrumen peneliti menguji instrumen social desirability yang telah dikembangkan berdasarkan temuan pada tahap 1 .

Teknik analisis data yang digunakan dalam penelitian ini terdiri dari open coding, analisis item untuk mengetahui kualitas item alat ukur, estimasi reliabilitas yang menggunakan Alpha, serta uji validitas menggunakan validitas faktorial, validitas konvergen.

\section{HASIL}

Tahapan pertama dalam penelitian adalah eksplorasi tema item. Metode pengambilan data eksplorasi dalam penelitian ini menggunakan instrumen open ended questionnaire 
mengikuti bentuk pertanyaan yang sama dengan yang pernah digunakan oleh Stober (2000). Peneliti kemudian melakukan sedikit modifikasi pertanyaan dengan mendasarkan pada penjelasan yang diberikan oleh Jaya, Hartana \& Mangundjaya (2012) yang menyatakan bahwa item favorable dalam skala social desirability yang dibuat Marlowe \& Crowne (1963) menunjukan perilaku yang dianggap baik namun jarang dilakukan, sementara item unfavorable menunjukan perilaku yang dianggap kurang baik/buruk oleh masyarakat namun hampir semua orang pernah melakukan, sehingga bentuk pertanyaan terbuka yang digunakan dalam penelitian ini adalah sebagai berikut: 1) Ceritakan perilaku baik yang menurut Anda jarang Anda lakukan!, 2) Ceritakan perilaku kurang baik yang menurut Anda seringkali Anda lakukan!

Hasil eksplorasi tahap 1 menemukan 15 tema yang memiliki persentase terbanyak yang kemudian dijadikan sebagai model yaitu attention dan denial untuk kemudian dikembangkan menjadi instrumen.

Tabel 1

Model Dua Faktor Attention dan Denial

\begin{tabular}{ll}
\hline Attention & Denial \\
\hline Memberi & Egois \\
Membantu & Apatis \\
Sabar & Berkata kasar \\
Ramah & Berbohong \\
Silaturahmi & Telat \\
Suka Menyapa & Mudah marah \\
Ikhlas & Malas \\
& Membicarakan keburukan orang \\
\hline
\end{tabular}

Setelah peneliti menyusun blue-print skala, prosedur selanjutnya adalah penulisan item yang akan digunakan. Penulisan item ini mengacu pada tema hasil penemuan di atas. Karena jumlah tema pada item favorable lebih sedikit daripada item unfavorable, peneliti memutuskan untuk membuat tambahan satu item dengan tema favorable yang memliki jumlah persentase terbanyak, yaitu tema memberi. Sehingga, jumlah total item yang dibuat adalah sebanyak 16 item. Langkah selanjutnya setelah pembuatan item adalah peneliti mengestimasi nilai reliabilitas dan menguji validitas konstruk skala social desirability yang telah dikembangkan dengan menggunakan model dua faktor yang diajukan oleh Rahmanaiah dkk (1980).

Hasil estimasi reliabilitas skala social desirability yang dikonstruksi pada tahap kedua menunjukan nilai reliabilitas alpha cronbach yang tinggi $\alpha=0.76$ (Guilford, 1956). Hasil ini dengan kata lain juga menunjukan bahwa skala yang telah dikembangkan telah memiliki reliabilitas yang baik dan taraf kepercayaan yang tinggi.

Analisis validitas konstruk yang dilakukan dalam penelitian ini adalah dengan pendekatan analisis faktor/faktorial dan validitas konvergen. 
Tabel 2 merupakan analisis validitas faktorial dengan menggunakan model dua faktor dari Ramaniah dkk (1977) yaitu attention dan denial dengan jumlah responden sebanyak 501 partisipan. Analisis validitas faktorial yang dilakukan dalam penelitian ini adalah dengan menggunakan Confirmatory Factor Analysis (CFA).

CFA digunakan dalam penelitian ini untuk menguji skala dengan menggunakan model dua faktor skala social desirability dari Ramanaiah, dkk (1977) dengan didasarkan pada indeks kecocokan/parameter model fit. Indeks kecocokan yang digunakan untuk menguji model fit dalam penelitian ini diantaranya adalah Goodness of Fit Index (GFI), Root Mean Square Error of Approximation (RMSEA), Standardized Root Mean Residual (SRMR), Comparative Fit Index (CFI).

Tabel 2

Analisis Faktor Konfirmatori Skala Social Desirability Indonesia

\begin{tabular}{|c|c|c|}
\hline Pernyataan & DENIAL & ATTENTION \\
\hline $\begin{array}{l}\text { Saya kadang bertindak seenaknya meskipun saya tahu hal tersebut } \\
\text { merugikan orang lain. (EGOIS) }\end{array}$ & 0,55 & \\
\hline $\begin{array}{l}\text { Saya kadang tidak menaruh perhatian pada orang yang sedang mengobrol } \\
\text { serius dengan Saya. (TIDAK PEDULI) }\end{array}$ & 0,43 & \\
\hline $\begin{array}{l}\text { Saya cenderung ingin berkata kasar saat merasa kesal. (BERKATA } \\
\text { KASAR) }\end{array}$ & 0,51 & \\
\hline $\begin{array}{l}\text { Saya akan berbohong jika saya pikir tidak akan ada orang yang tahu. } \\
\text { (BERBOHONG) }\end{array}$ & 0,58 & \\
\hline $\begin{array}{l}\text { Saya kadang telat menyelesaikan suatu pekerjaan karena mudah teralihkan. } \\
\text { (TELAT) }\end{array}$ & 0,38 & \\
\hline $\begin{array}{l}\text { Saya cenderung mudah terpancing emosi saat suasana hati sedang buruk } \\
\text { (badmood). (MUDAH MARAH) }\end{array}$ & 0,34 & \\
\hline $\begin{array}{l}\text { Saya kadang malas melaksanakan kewajiban, jika tidak ada yang } \\
\text { mendorong saya melakukannya. (MALAS) }\end{array}$ & 0,50 & \\
\hline $\begin{array}{l}\text { Saya kadang kala membicarakan perilaku negatif orang lain saat mengobrol } \\
\text { dengan teman. (MEMBICARAKAN PERILAKU BURUK ORANG) }\end{array}$ & 0,48 & \\
\hline Saya tidak pernah pamrih saat membantu orang lain. (IKHLAS) & & 0,48 \\
\hline $\begin{array}{l}\text { Jika Saya memberikan pinjaman uang pada orang lain, Saya melakukannya } \\
\text { dengan senang hati. (MEMBERI) }\end{array}$ & & 0,39 \\
\hline Saya selalu bersabar saat menghadapi musibah. (SABAR) & & 0,56 \\
\hline $\begin{array}{l}\text { Saya selalu menjaga komunikasi dengan teman-teman lama saya. } \\
\text { (SILATURAHMI) }\end{array}$ & & 0,47 \\
\hline $\begin{array}{l}\text { Saya selalu berinisiatif menyapa orang yang saya kenal saat tidak sengaja } \\
\text { bertemu di jalan. (MENYAPA) }\end{array}$ & & 0,53 \\
\hline $\begin{array}{l}\text { Saya selalu menyisihkan sebagian uang saya untuk diberikan pada mereka } \\
\text { yang kurang mampu. (MEMBERI) }\end{array}$ & & 0,58 \\
\hline $\begin{array}{l}\text { Saya selalu membantu orang lain meskipun Saya sendiri sedang dalam } \\
\text { kesulitan. (MEMBANTU) }\end{array}$ & & 0,53 \\
\hline Saya selalu bersikap ramah pada setiap orang tanpa terkecuali (RAMAH) & & 0,61 \\
\hline
\end{tabular}

Chi Square: 280.000, df: 103, p-value: 0,000, RMSEA: 0,059 
Hasil analisis validitas konstruk dengan menggunakan CFA menunjukan bahwa skala social desirability yang dikembangkan dalam penelitian ini fit dengan data. Secara lebih rinci, Skala social desirability Indonesia memiliki nilai indeks kecocokan model CFI $=0.92$, $\mathrm{GFI}=0.93, \mathrm{RMSEA}=0.059$, dan $\mathrm{SRMR}=0.052$.

Uji validitas konstruk lain yang digunakan dalam penelitian ini adalah validitas konvergen. Uji validitas ini dilakukan dengan mengkorelasikan skala social desirability Indonesia dengan skala social desirability dari Reynolds (1982). Hasil uji korelasi menunjukan bahwa skala social desirability Indonesia secara signifikan berkorelasi dengan skala social desirability dari Reynolds (1982) dan memiliki nilai korelasi sebesar 0.558. Nilai koefisien tersebut mengindikasikan korelasi yang sedang/moderate (Guillford, 1956).

Hasil tersebut menunjukan bahwa skala social desirability Indonesia memiliki bukti validitas konvergen, karena berkorelasi secara signifikan dengan skala yang memiliki konstruk yang sama.

Berdasarkan analisis data dan pembahasan yang telah diuraikan sebelumnya, kesimpulan yang dapat diperoleh dari penelitian kali ini adalah: 1) Skala social desirability Indonesia memiliki reliabilitas yang baik dan masuk kedalam kategori reliabilitas yang tinggi dengan nilai koefisien alpha cronbach sebesar $\alpha=0.76$. 2) Hasil validitas faktorial dengan confirmatory factor analysis, menunjukan Skala social desirability Indonesia yang diuji dalam penelitian ini dinyatakan fit dengan data. 3) Validitas Konvergen yang diuji dengan mengkorelasikan antara skala social desirability Indonesia dan skala social desirability dari Reynolds (1982) menunjukan hasil korelasi yang signifikan dan berada pada tingkat korelasi sedang. Sehingga, skala social desirability Indonesia dapat dikatakan memiliki bukti validitas konvergen.

\section{DAFTAR PUSTAKA}

Anggoro, W. A., \& Widhiarso, W. (2010). Konstruksi dan identifikasi properti psikometris skalat pengukuran kebahagiaan berbasis pendekatan indigenous psychology: studi multitrait-multimethod. Jurnal Psikologi. 37(2), hlm. 176-188.

Barrick, M. R., \& Mount, M. K. (1996). Effects on impression management and selfdeception on the predictive validity of personality construct. Journal of applied psychology, 81, hlm. 261-272

Collazo, A. A., (2005) Translation of the Marlowe-crowne social desirability scale into equivalent spanish version. Educational and psychological Measurenment, 65(5).

Dijkstra, W., Smit, J. H., \& Comijs, H. C. (2001). Using social desirability scales ini research among the elderly. Quality and Quantity, 35, hlm. 107.

Espinosa \& Vijver (2016). An indigenous social desirability scale. Measurent and Evaluation in counseling and development,47(3), hlm. 199-214. 
Guilford, J.P. (1956). Fundamental statistic in psychology and education, $3^{\text {rd }}$ Edition.New York: McGraw-Hill Book Company, Inc.

Jaya, Hartana \& Mangundjaya (2011). Menyidik keberadaan social desirability (SD) pada variabel penelitian perilaku. Jurnal Psikologi Indonesia, 7(1).

Kim, U. \& Berry, J.W. (1993). Indigenous psychologies: experience and research in cultural context. Newbury Park: Sage Publication.

Kim, U., Yang, K., Hwang, K. (2006). Contributions to Indigenous and Cultural Psychology: Understanding People in Context. Dalam Kim, U., Yang, K., \& Hwang., (Penyunting). Indigenous and Cultural Psychology: Understanding People in Context. New York: Springer.

Ramanaiah, N. V., Schill, T \& Leung, L. L. (1977). A test of the hypothesis about the twodimensional nature of the Marlowe-crowne social desirability scale. Journal of Research in Personality, 11, hlm. 251-259.

Reynolds, W.M. (1982). Develpomant of reliable and valid short forms of the Marlowe crowne social desirability scale. Journal of Clinical Psychology, 1982, 38(1).

Stober, J. (2000). The Social Desirability Scale-17 (SDS-17):Convergent validity, discriminant validity, and relationship with age. European Journal of Psychological Assesment, 17, 222-232.

Paulhus, D., L. (2002). Socially desirable responding: the evolution of a construct. Dalam H. I. Braun, D. N. Jackson, \& D.E Wiley, The role of construct in psychological and education.

Tabachnik, B.G., \& Fidell.,L.,S. (2007). Using multivariate statistics for the social sciences ( $4^{\text {th }}$ ed.). Hillsdale, NS: Erlbaum

Van Voorhis, C. R. W., \& Morgan, B. L. (2007). Understanding power and rules of thumb for determining sample sizes. Tutorial in Quantitative Methods for Psychology, 3(2), hlm. 43-50. 